\title{
Two Oxytrichid Ciliates, Cyrtohymena primicirrata and Oxytricha granulifera (Ciliophora: Sporadotrichida: Oxytrichidae) Unknown from Korea
}

\author{
Choon Bong Kwon, Mann Kyoon Shin* \\ Department of Biological Science, University of Ulsan, Ulsan 680-749, Korea
}

\begin{abstract}
This study reports the discovery of two oxytrichid ciliates, Cyrtohymena primicirrata (Berger and Foissner, 1987) and Oxytricha granulifera Foissner and Adam, 1983, in Jeju Island, Korea. The morphology of the two species was studied using live observation and protargol impregnation. These species are described as follows: Cyrtohymena primicirrata has a body size in live specimens $90-140 \times 40-60 \mu \mathrm{m}$, length : width ratio $2.3: 1$ on average; elongated and slender obovate in outline of body. Cortical granules are shiny yellow on the ventral and dorsal side. Adoral zone of membranelles (AZM) is covering about $48 \%$ of the cell with about 38 adoral membranelles. Arrangement of undulating membranes is ordinary Cyrtohymena pattern. Dorsal kineties is six rows with $5 \mu \mathrm{m}$ long bristles. Oxytricha granulifera has a body size in live specimens $90-115 \times 25-38 \mu \mathrm{m}$, length: width ratio 3.31 on average; elongated ellipsoidal in outline of body. Cortical granules are colorless on the ventral and dorsal side. AZM is covering 28\% of the cell length in vivo with about 24 adoral membranelles. Arrangement of undulating membranes is Oxytricha pattern. Dorsal kineties is five rows with about $3 \mu \mathrm{m}$ long dorsal bristles.
\end{abstract}

Keywords: Cyrtohymena, Oxytricha, morphology, Jeju Island, freshwater

\section{INTRODUCTION}

Genera Cyrtohymena Foissner, 1989 and Oxytricha Bory de saint Vincent, 1824 belong to the family Oxytrichidae Ehrenberg, 1838, that is characterized by having typically 18 frontoventral-transverse cirral patterns on the ventral side (Berger, 1999).

So far, more than 16 species of the genus Cyrtohemena have been described in the world (Berger, 1999; Foissner, 2004), and four species have been recorded in Korea: $C$. australis Foissner, 1995, C. citrina (Berger and Foissner, 1987) Foissner, 1989, C. muscorum (Kahl, 1932) Foissner, 1989, and C. quadrinucleata (Dragesco and Njine, 1971) Foissner, 1989 (Kim et al., 2012). Cyrtohymena have highly prominent undulating membranes known as Cyrtohymena pattern, resulting in very transparent buccal cavity (Berger, 1999; Kim et al., 2012).

The genus Oxytricha was established by Bory de Saint Vincent in Lamouroux et al. (1824) under name of Oxitricha.
The nominal species of genus Oxytricha are over 50 species (Berger, 1999, 2001; Eigner, 2001) and then seven species have been recorded in Korea: O. balladyna Song and Wilbert, 1989, O. fallax Stein, 1859, O. marina Kahl, 1932, O. longa Gelei and Szabados, 1950, O. longigranulosa Berger and Foissner, 1989, O. rubripuncta Berger and Foissner, 1987, and O. saltans (Cohn, 1866) Rees, 1881 (Shin and Kim, 1993; The Korean Society of Systematic Zoology, 1997; Berger, 1999; Kwon and Shin, 2004, 2008). In this study, we describe two oxytrichid species of Korean ciliate populations that are new to Korea, C. primicirrata and O. granulifera, based on live and protargol impregnated specimens.

\section{MATERIALS AND METHODS}

\section{Sampling}

Cyrtohymena primicirrata and Oxytricha granulifera were collected from freshwater wetlands in Dong-Back Hill, Seon-
(C) This is an Open Access article distributed under the terms of the Creative Commons Attribution Non-Commercial License (http://creativecommons.org/ licenses/by-nc/3.0/) which permits unrestricted non-commercial use, distribution, and reproduction in any medium, provided the original work is properly cited.

pISSN 2234-6953 eISSN 2234-8190
*To whom correspondence should be addressed

Tel: 82-52-259-2396, Fax: 82-52-259-1694

E-mail: mkshin@ulsan.ac.kr 
heul-ri, Jeju, on September 26, 2011 and February 26, 2012 (C. primicirrata only) with some water plants and detritus. The collected samples were moved to the laboratory and were kept insulated from temperature rise.

\section{Observation and stain}

The live specimens were observed using bright field and differential interference contrast microscopy (Axio Imager A1; Carl Zeiss, Oberkochen, Germany) equipped with a camera (Axio Cam MRc; Carl Zeiss) to observe body shape, size, cortical granules, food vacuoles, ciliary features, other cytoplasm and oral apparatus. Staining with protargol was performed as described by Wilbert (1975), with saturated $\mathrm{HgCl}_{2}$ for cell fixation. Cell counts and measurements on silver impregnated specimens were performed using a compound microscope (Olympus BX 50; Olympus, Tokyo, Japan) equipped with a camera (Moticam Pro; Motic, Hong Kong, China). The drawings of live and impregnated specimens were based on free-hand sketches and Illustrator 10 (Adobe), as well as photomicrographs and a drawing device was used.

The taxonomical classification and terminology are according to Berger (1999).

\section{SYSTEMATIC ACCOUNTS}

Subclass Stichotrichia Small and Lynn, 1985

Order Sporadotrichida Fauré-Fremiet, 1961

Family Oxytrichidae Ehrenberg, 1838

Genus Cyrtohymena Foissner, 1989

\section{${ }^{1 *}$ Cyrtohymena primicirrata (Berger and Foissner, 1987) Foissner, 1989 (Table 1, Figs. 1-3)}

Steinia platystoma: Dragesco, 1970: 119.

Steinia inquieta: Foissner, 1984: 115.

Steinia primicirrata Berger and Foissner, 1987: 227.

Steinia ultricirrata: Foissner, 1987: 127.

Cyrtohymena primicirrata: Foissner, 1989: 239; Berger, 1999: 300.

Description. General features: Body size 90-140 × 40-60 $\mu \mathrm{m}$, usually $110 \times 45 \mu \mathrm{m}$, length : width ratio $2.3: 1$ on average in live specimens. Body outline elongated and slender obovate; broadest at level of buccal vertex, anterior broadly rounded with distinct anterior collar, posterior end gradually narrowed and round, right margin slightly convex, left margin convex (Figs. 1A, 2A). Body flexible. Contractile vacuole

Table 1. Morphometric data on Cyrtohymena primicirrata (C.p.) and Oxytricha granulifera (O.g.)

\begin{tabular}{|c|c|c|c|c|c|c|c|c|c|}
\hline Characteristics & & Mean & Med & Min & Max & SD & SE & $\mathrm{CV}$ & $\mathrm{n}$ \\
\hline \multirow[t]{2}{*}{ Body length } & C.p. & 133 & 135 & 104 & 163 & 16.99 & 4.54 & 12.82 & 14 \\
\hline & O.g. & 88 & 87 & 60 & 112 & 10.48 & 2.10 & 11.96 & 25 \\
\hline \multirow[t]{2}{*}{ Body width } & C.p. & 57 & 57 & 34 & 75 & 12.14 & 3.24 & 21.46 & 14 \\
\hline & O.g. & 38 & 40 & 26 & 47 & 5.46 & 1.09 & 14.26 & 25 \\
\hline \multirow[t]{2}{*}{ Body length/width, ratio } & C.p. & 2 & 2 & 2 & 3 & 0.35 & 0.09 & 14.63 & 14 \\
\hline & O.g. & 2 & 2 & 2 & 3 & 0.28 & 0.06 & 11.94 & 25 \\
\hline AZM, length & O.g. & 31 & 30 & 26 & 35 & 2.42 & 0.48 & 7.89 & 25 \\
\hline \multirow[t]{2}{*}{ AZM:body length, ratio } & C.p. & 44 & 43 & 41 & 53 & 4.05 & 1.08 & 9.12 & 14 \\
\hline & O.g. & 24 & 24 & 21 & 26 & 1.41 & 0.28 & 5.94 & 25 \\
\hline \multirow[t]{2}{*}{ Adoral membranelles, number } & C.p. & 38 & 38 & 35 & 44 & 2.90 & 0.77 & 7.56 & 14 \\
\hline & O.g. & 24 & 24 & 21 & 26 & 1.41 & 0.28 & 5.94 & 25 \\
\hline \multirow[t]{2}{*}{ Right marginal cirri, number } & C.p. & 20 & 20 & 17 & 23 & 1.69 & 0.47 & 8.36 & 13 \\
\hline & O.g. & 24 & 24 & 20 & 28 & 1.97 & 0.39 & 8.19 & 25 \\
\hline Caudal cirri, number & O.g. & 3 & 3 & 2 & 3 & 0.22 & 0.05 & 7.39 & 21 \\
\hline \multirow[t]{2}{*}{ Left marginal cirri, number } & C.p. & 17 & 17 & 16 & 18 & 0.60 & 0.17 & 3.57 & 13 \\
\hline & O.g. & 22 & 23 & 18 & 25 & 1.73 & 0.35 & 7.73 & 25 \\
\hline \multirow[t]{2}{*}{ Macronuclei, length } & C.p. & 18 & 18 & 12 & 22 & 2.99 & 0.83 & 16.65 & 13 \\
\hline & O.g. & 15 & 15 & 10 & 21 & 2.78 & 0.56 & 18.73 & 25 \\
\hline \multirow[t]{2}{*}{ Macronuclei, width } & C.p. & 14 & 13 & 10 & 17 & 2.36 & 0.65 & 17.23 & 13 \\
\hline & O.g. & 10 & 10 & 8 & 11 & 0.84 & 0.17 & 8.81 & 25 \\
\hline \multirow[t]{2}{*}{ Micronuclei, diameter } & C.p. & 4 & 4 & 3 & 5 & 0.50 & 0.14 & 13.80 & 13 \\
\hline & O.g. & 3 & 3 & 2 & 4 & 0.36 & 0.07 & 12.10 & 24 \\
\hline
\end{tabular}

Measurements in $\mu \mathrm{m}$. All data are based on protargol-impregnated specimens.

Med, medium; Min, minimum; Max, maximum; SD, standard deviation; SE, standard error of arithmetic mean; CV, coefficient of variation (\%); $\mathrm{n}$, number of individuals investigated; AZM, adoral zone of membranelles. 

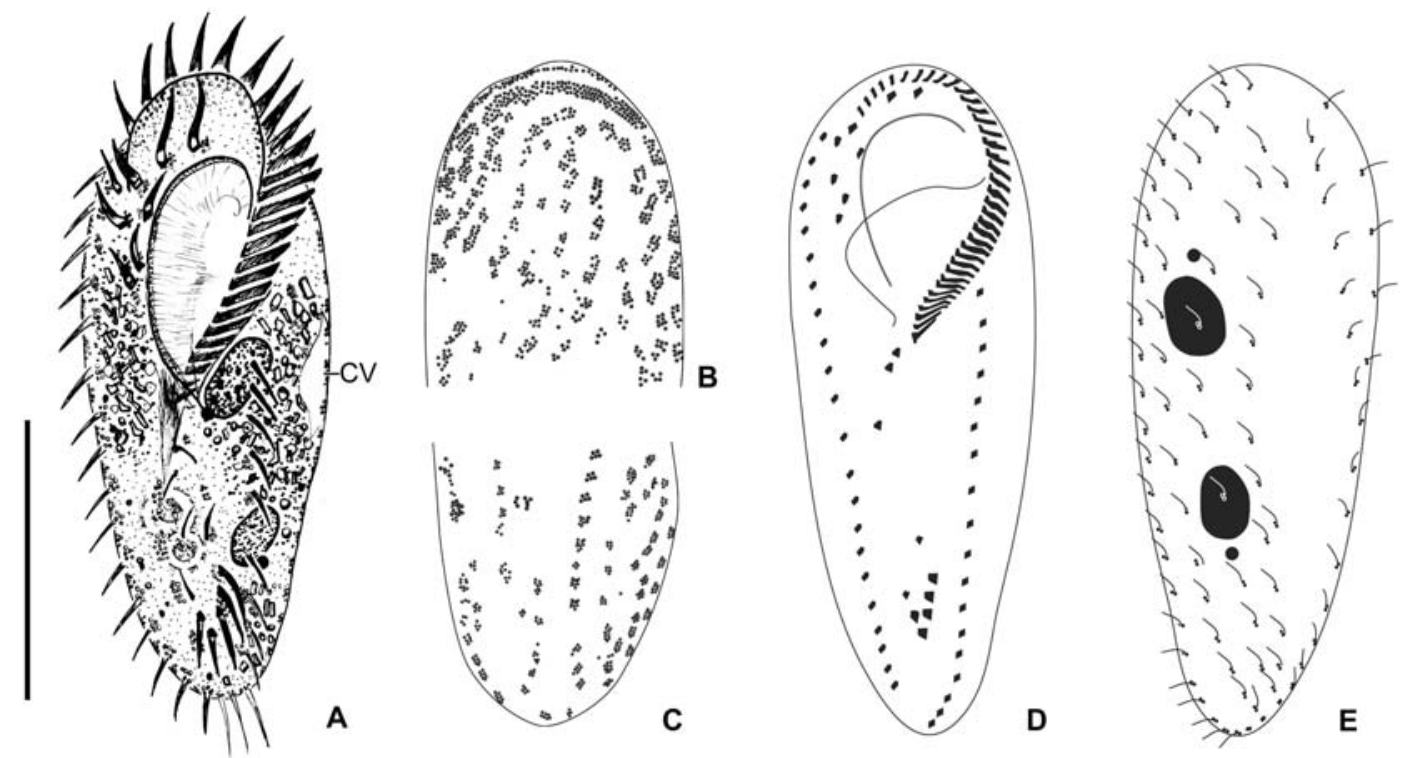

Fig. 1. Morphology and infraciliature of Cyrtohymena primicirrata from live specimens $(A-C)$ and after protargol impregnation (D, E). A, Ventral view of live specimen; B, Cortical granules on dorsal side; C, Cortical granules on ventral side; D, Ventral view of general infraciliature; $E$, Dorsal kineties and nuclear apparatus. CV, contractile vacuole. Scale bar: $A=50 \mu \mathrm{m}$.
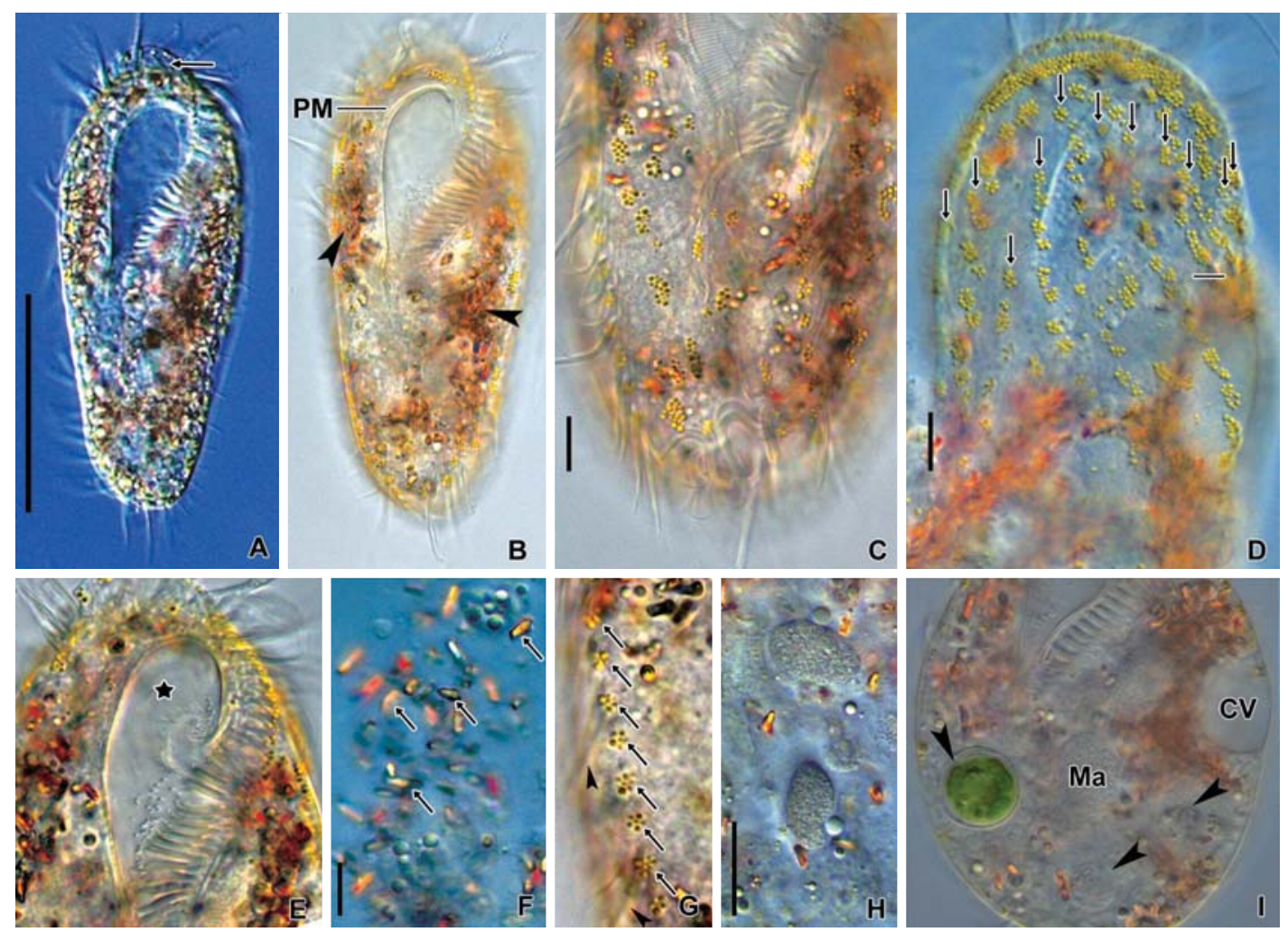

Fig. 2. Morphology of Cyrtohymena primicirrata from live specimens. A, Ventral view at low magnification; B, Ventral view of live specimen, arrowheads show crystals; C, Cortical granules on ventral side; D, Cortical granules rows (arrows) on dorsal side; E, Buccal region (star); F, Crystals (arrows); G, Cortical granules (arrows) beside marginal cirri (arrowheads); $\mathrm{H}$, Macro and micronuclei; I, Food vacuoles (arrowheads), macronucleus (Ma) and contractile vacuole (CV). PM, paroral membrane. Scale bars: $A=50 \mu m, C, D$, $\mathrm{F}=10 \mu \mathrm{m}, \mathrm{H}=20 \mu \mathrm{m}$. 

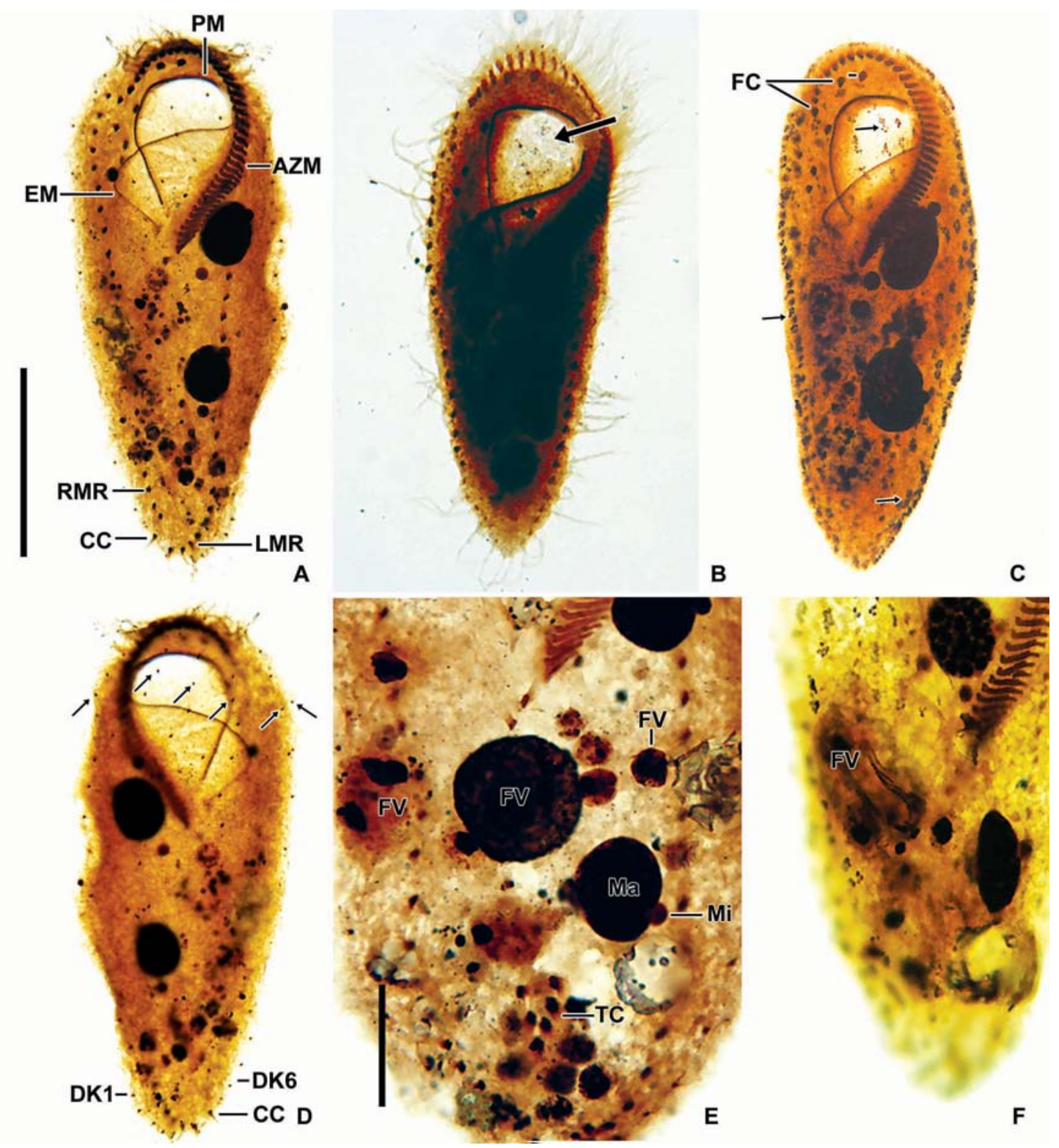

Fig. 3. Morphology and infraciliature of Cyrtohymena primicirrata after protargol impregnation. $A$, Ventral view of general infraciliature; B, Buccal region (arrow); C, Cortical granules (arrows) after protargol impregnation; D, Dorsal kineties (arrows) and caudal cirri; E, Food vacuoles, macronuclear and micronuclear nodules; F, Food vacuoles. AZM, adoral zone of membranelles; CC, caudal cirri; DK, dorsal kinety; EM, endoral membrane; FC, forntal cirri; FV, food vacuole; LMR, left marginal cirral row; Ma, macronucleus; Mi, micronucleus; PM, paroral membrane; RMR, right marginal cirral row; TC, transverse cirri. Scale bars: $A=50 \mu \mathrm{m}, E=20 \mu \mathrm{m}$.

located near left margin of the cell in mid body, during diastole with short collecting canals (Figs. 1A, 2I). Cytoplasm colorless, but sparsely darkened at low magnification owing to food vacuoles and crystals (Fig. 2A, B). Crystals presented in both margin of body densely and sized 3-5 × 1-2 $\mu \mathrm{m}$ (Fig. $2 \mathrm{~B}, \mathrm{~F})$. Yellowish cortical granules arranged as a aciniform in groups composed of three to 20 granules; at least 10 rows longitudinally on dorsal side; the marginal and ventral cirri on the ventral side; each granule spherical shaped with about $1 \mu \mathrm{m}$ in diameter (Figs. 1B, C, 2C, D, G, 3C). Food vacuoles contained diatoms, small ciliate or green algae (Figs. 2I, 3E, F). Movement moderated.

Buccal field and oral infraciliature: Adoral zone of membranelles covered about $48 \%$ of the cell length in vivo and $44 \%$ in impregnated specimens, composed of about 38 adoral membranelles, bases of largest membranelle in live specimens 
about $9 \mu \mathrm{m}$ broadly. Buccal field huge and prominent, a safety pin shaped like, owing to the large hole at low magnification (Fig. 2A). Undulating membranes ordinary Cyrtohymena patterned with paroral and endoral membranes; the distal portion of paroral membrane semicircularly curved; anterior half of the endoral membrane extended diagonally on the bottom of buccal cavity (Figs. 1D, 2B, E).

Somatic infraciliature: Frontal, ventral and transverse cirri constantly composed of 18 cirri. Buccal cirrus present beside middle part of paroral membrane. Three post-oral-ventral cirri. Two pretransverse cirri. Usually five transverse cirri arranged in sharply V-shape and placed anteriad (Figs. 1D, 3D). Right and left marginal cirri separated at posterior end (Figs. 1D, 3A). Three caudal cirri about $20 \mu \mathrm{m}$ long in vivo and inserted in gap between both marginal rows on the dorsal side (Fig. 3A, D). Dorsal kineties six rows with $5 \mu \mathrm{m}$ long bristles (Figs. 1E, 3D). Morphometric features of Korean population of $C$. primicirrata shown Table 1 .

Nuclear apparatus: Always two macronuclei, the upper one about $18 \times 14 \mu \mathrm{m}$ in impregnated specimens, located on the left of the proximal region of adoral zone of membranelles (Figs. 1E, 2H, 3A, E). Two micronuclei $3-4 \mu \mathrm{m}$ in diameter, each one attached to each macronucleus.

Distribution. Europe (Austria), Africa (Cameroon), Asia (Korea).
Remarks. The Korean population of Cyrtohymena primicirrata agrees with descriptions of other populations as following characters: 1) having two macronuclei and usually two micronuclei, 2) having yellowish cortical granules, 3) occurrence in freshwater, 4) body length less than $200 \mu \mathrm{m}$, and 5) anteriad position of transverse cirri (Dragesco, 1970; Berger, 1999).

Cyrtohymena primicirrata, C. australis Foissner, 1995, and C. citrina (Berger and Foissner, 1987) Foissner, 1989 are easily confusable by yellowish cortical granules. However, $C$. primicirrata is different from $C$. australis in body length (90-140 $\mu \mathrm{m}$ vs. $200-400 \mu \mathrm{m})$ and arrangement of transverse cirri (sharply V-shaped vs. slightly oblique shaped). Cyrtohymena primicirrata is distinguished from $C$. citrina with body shape (elongate and obovate vs. slender) and position of transverse cirri (anteriad vs. posteriad).

Genus Oxytricha Bory de Saint-Vincent in Lamouroux et al., 1824

\section{${ }^{1 *}$ Oxytricha granulifera Foissner and Adam, 1983 \\ (Table 1, Figs. 4-6)}

Oxytricha granulifera Foissner and Adam, 1983: 1; Foissner, 1989: 235; Berger, 1999: 197.
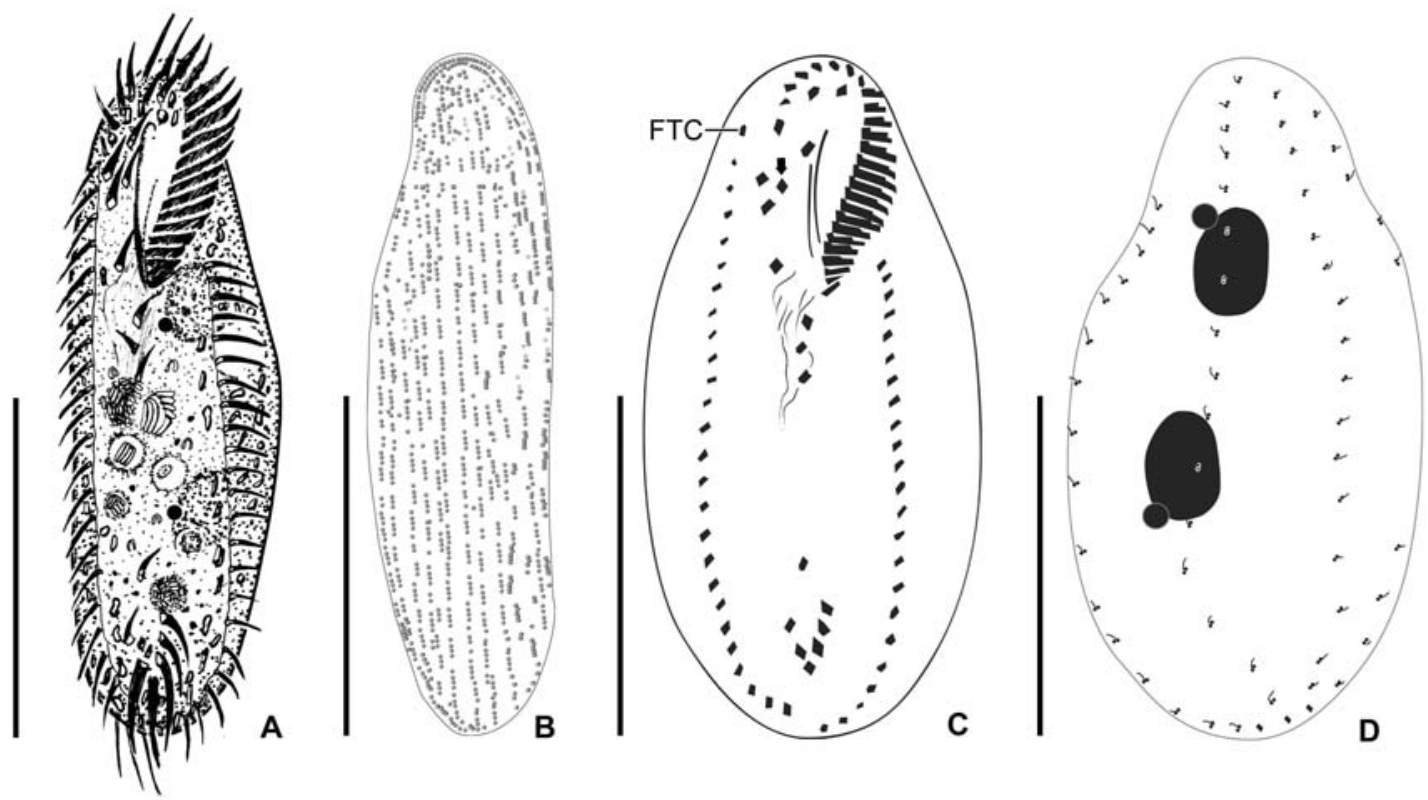

Fig. 4. Morphology and infraciliature of Oxytricha granulifera from live specimens (A, B) and after protargol impregnation (C, D). $A$, Ventral view of live specimen; $B$, Cortical granules on dorsal side; C, Ventral view of general infraciliature; $D$, Dorsal kineties and nuclear apparatus. FTC, fronto-terminal cirrus. Scale bars: $A-D=50 \mu \mathrm{m}$.

Korean name: ${ }^{1 *}$ 과립첨모하모충 

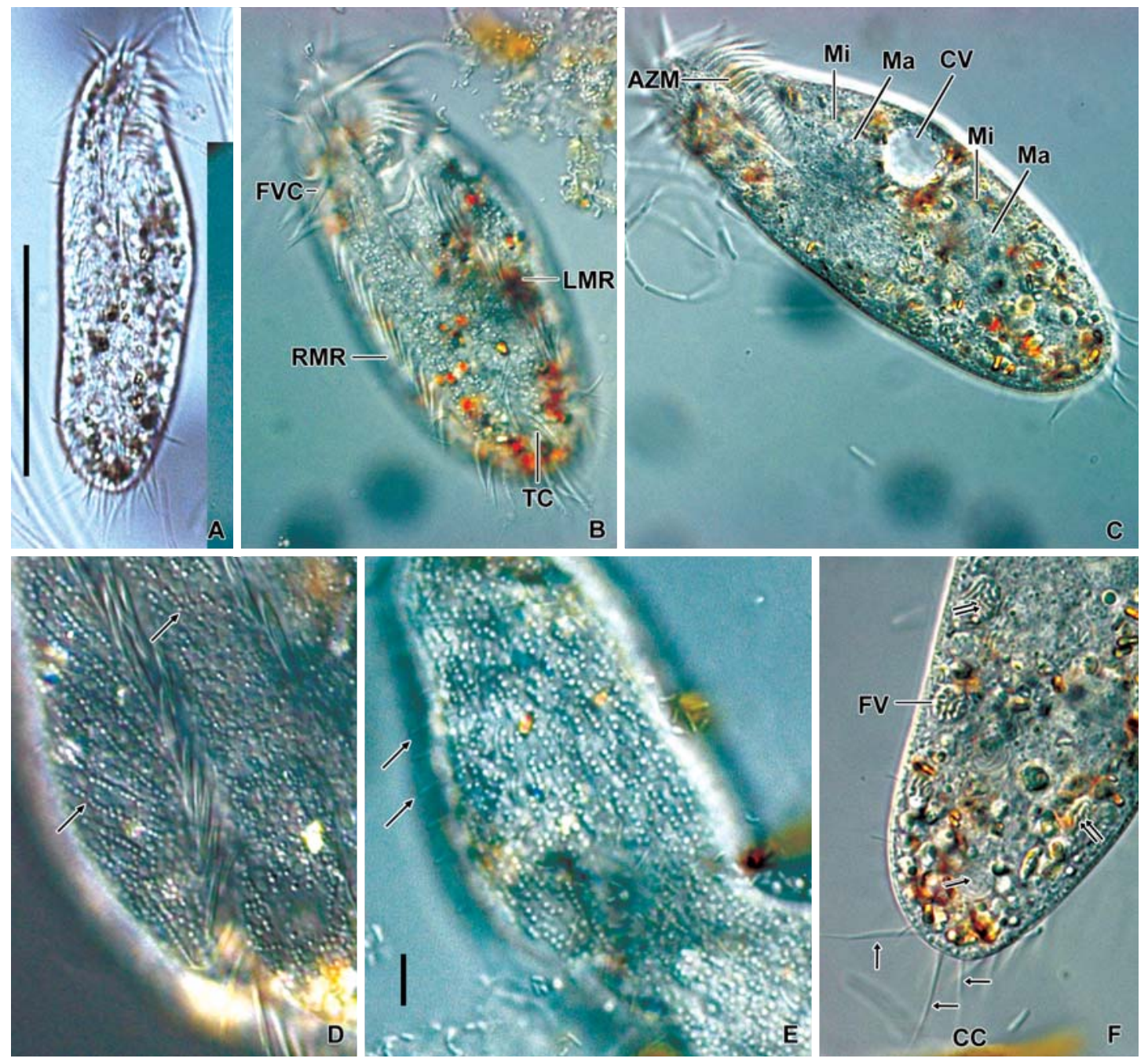

Fig. 5. Morphology of Oxytricha granulifera from live specimens. A, Ventral view at low magnification; B, Cirral apparatus on ventral side; C, Nuclear apparatus and contractile vacuole; D, Cortical granules (arrows) on ventral side; E, Cortical granules, arrows denote dorsal bristles; F, Cytoplasms, crystals (double arrows) and food vacuoles. AZM, adoral zone of membranelles; CC, caudal cirri (arrows in F); CV, contractile vacuole; FV, food vacuole; FVC, front-ventral cirrus; LMR, left marginal cirral row; Ma, macronucleus; $\mathrm{Mi}$, micronucleus; RMR, right marginal cirral row; TC, transverse cirri. Scale bars: $A=50 \mu \mathrm{m}, E=10 \mu \mathrm{m}$.

Description. General features: Body size $90-115 \times 25-38$ $\mu \mathrm{m}$, usually $100 \times 33 \mu \mathrm{m}$ in vivo, length : width ratio 3.31 on average in live specimens. Body outline elongated ellipsoidal. The anterior body narrowly rounded with distinct anterior collar, posterior end broadly rounded, right margin usually straight, sometimes slightly convex, left margin distinctly convex (Figs. 4A, 5A, C, F). Body flexible. Contractile vacuole located near left margin of cell in mid body, during diastole with two collecting canals (Fig. 5C). Cytoplasm colorless, with yellowish crystals sized about $4 \mu \mathrm{m}$ in length, scattered in entire body and densely packed in anterior, posterior and marginal regions. Cortical granules colorless about $1 \mu \mathrm{m}$ in diameter; linearly arranged three to seven granules longi- tudinally on the dorsal side; irregularly arranged on the ventral side (Figs. 4B, 5D, E). Food vacuoles about $10 \mu \mathrm{m}$ in diameter; contained with bacteria, fungi and flagellate in protargol specimens (Fig. 5F). Locomotion moderate and rapid. Buccal field and oral infraciliature: Adoral zone of membranelles shaped question mark, covered $28 \%$ of the cell length in vivo and $24 \%$ in impregnated specimens, composed of the average 24 adoral membranelles. Buccal cavity narrow (Figs. 4A, 5C). Undulating membranes consisted of endoral and paroral membranes; both membranes positioned parallel to each other and slightly curved, sometimes crossed at the proximal region. Pharyngeal fibers at base of buccal field, and about $30 \mu \mathrm{m}$ long; extended to near right margin of the 


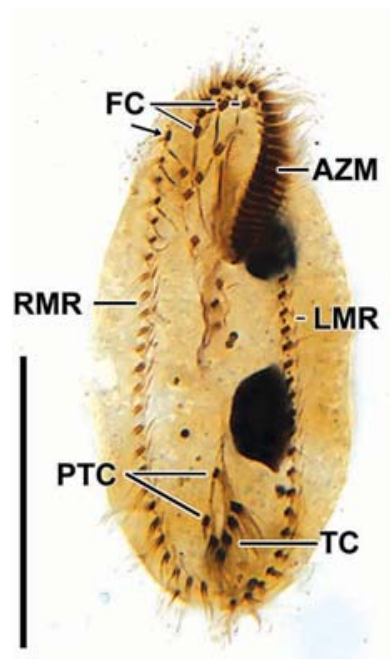

A

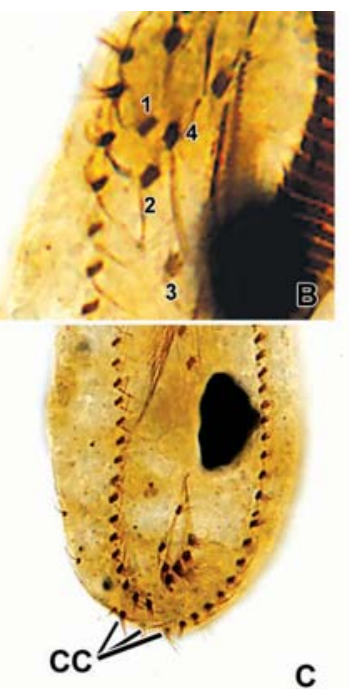

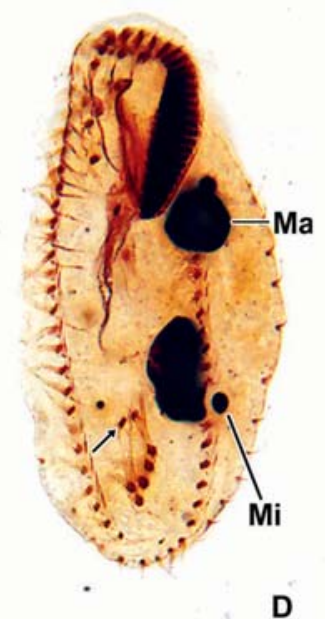

D

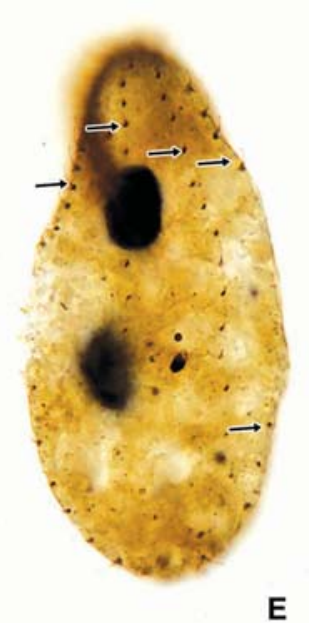

$\mathbf{E}$

Fig. 6. Morphology and infraciliature of Oxytricha granulifera after protargol impregnation. A, Ventral view of general infraciliature; $B$, The arrangement of frontoventral cirri; C, Caudal cirri; D, Nuclear apparatus, arrow denotes various position of pre-ventral cirri; $\mathrm{E}$, Dorsal kineties (arrows). AZM, adoral zone of membranelles; CC, caudal cirri; FC, frontal cirri; LMR, left marginal cirral row; Ma, macronucleus; Mi, micronucleus; PTC, pretransverse cirrus; RMR, right marginal cirral row; TC, transverse cirri. Scale bar: $A=50 \mu \mathrm{m}$.

body (Fig. 6A, D).

Somatic infraciliature: Frontal, ventral and transverse cirri composed of 18 cirri (Fig. 5B). Three frontal cirri present (Figs. 4C, 6A). Buccal cirrus presented beside distal end of undulating membranes. Four frontoventral cirri present (Figs. 4C, 6A, B). One fronto-terminnal cirrus. Three post-oralventral cirri. Two pretransverse cirri; some variations detected in their location (Fig. 6A, D). Five transverse cirri arranged as V-shape (Figs. 4C, 6A, C, D). Right and left marginal cirri separated at posterior end; each cirral row composed of about 24 and 24 cirri, respectively (Figs. 4C, 6A-D). Three caudal cirri thin and long (Figs. 5F, 6C). Dorsal kineties five rows with about $3 \mu \mathrm{m}$ long bristles in vivo (Figs. 4D, 5E, 6E).

Nuclear apparatus: Always two macronuclei, the upper one about $15 \times 10 \mu \mathrm{m}$ in impregnated specimens, located under the proximal region of adoral zone of membranelles. Two micronuclei about $3 \mu \mathrm{m}$ in diameter, each one attached to each macronucleus, sometimes three micronuclei (Figs. $4 \mathrm{D}, 5 \mathrm{C}, 6 \mathrm{D})$.

Distribution. Europe (Austria, Alpine), America (Costa Rica, Peru), Oceania (Australia), South Atlantic Ocean, Asia (Japan, Korea).

Remark. Oxytricha granulifera is well-known as type species of genera Oxytricha. This species was described so far only three times (Foissner and Adam, 1983; Foissner, 1989; Berger, 1999), despite the molecular study on this species have been studied by many investigators (Schlegel et al., 1991; Croft et al., 2003; Hewitt et al., 2003; Schmidt et al., 2007).

Korean population of Oxytricha granulifera agrees well with the chatacteristics of original description from Europe: 1) having two macronuclei and usually two micronuclei, 2) short dorsal bristles less than $6 \mu \mathrm{m}$ long, 3) about $100 \mu \mathrm{m}$ in body length, 4) symbiotic algae absent, 5) having colorless cortical granules, 6) body length: width ratio 2.2:1 (Berger, 1999). However, the Korean population was discovered from freshwater, whereas the European population was found in soil.

Oxytricha granulifera is different from $O$. longigranulosa in the arrangement of cortical granules (continued long rows vs. discontinued longitudinal rows of cortical granules), arrangement of both marginal cirri at posterior part (separated vs. overlaped) (Berger, 1999; Kwon and Shin, 2008).

Oxytricha granulifera is very similar to $O$. tenella Song and Wilbert, 1989 in common characters as two macronuclei and two micronuclei, less than $100 \mu \mathrm{m}$ in body length, short dorsal bristle, colorless cortical granules and similar numbers of both marginal cirri and adoral membranelles, except the ratio between length and width (3.0 vs. 1.6-1.75), arrangement of cortical granules (linear vs. irregular in drawings) and arrangement of fronto-ventral cirri (Foissner and Adam, 1983; Song and Wilbert, 1989; Berger, 1999).

\section{ACKNOWLEDGMENTS}

We thank two anonymous reviewers for their constructive comments. This work was supported by the National Research Foundation of Korea grant funded by the Korea government 
(no. C00138 and no. 2012R1A1A2005751).

\section{REFERENCES}

Berger H, 1999. Monograph of the Oxytrichidae (Ciliophora, Hypotrichia). Monographiae Biologicae, 78:1-1080.

Berger H, 2001. Catalogue of ciliate names. 1. Hypotrichs. Verlag Helmut Berger, Salzburg, pp. 1-206.

Berger H, Foissner W, 1987. Morphology and biometry of some soil hypotrichs (Protozoa: Ciliophora). Zoologische Jahrbücher Systematik, 114:193-239.

Croft KE, Dalby AB, Hogan DJ, Orr KE, Hewitt EA, Africa RJ, DuBois ML, Prescott DM, 2003. Macronuclear molecules encoding actins in spirotrichs. Journal of Molecular Evolution, 56:341-350.

Dragesco J, 1970. Ciliés libres du Cameroun. Annales de la Faculté des Sciences Universite Federale du Cameroun (Numéro Hors-serie), Yaounde, pp. 1-141.

Eigner P, 2001. Key to the species of the Hypotrichida (Protozoa, Ciliophora) on CD. Peter Eigner, Private Publisher, Deutsch Goritz.

Foissner W, 1984. Infraciliatur, silberliniensystem und biometrie einiger neuer und wenig bekannter terrestrischer, limnischer und mariner ciliaten: (Protozoa: Ciliophora) aus den klassen kinetofragminophora, Colpodea und Polyhymenophora. Stapfia, 12:1-165.

Foissner W, 1987. Soil protozoa: fundamental problems, ecological significance, adaptations in ciliates and testaceans, bioindicators, and guide to the literature. Progress in Protozoology, 2:69-212.

Foissner W, 1989. Morphologie und infraciliatur einiger neuer und wenig bekannter terrestrischer und limnischer ciliaten (Protozoa, Ciliophora). Sitzungsberichte der Osterreichischen Akademie der Wissenshaften, Mathematisch-Naturwissenschaftliche Klasse, Abt. I, 196:173-247.

Foissner W, 2004. Some new ciliates (Protozoa, Ciliophora) from an Austrian floodplain soil, including a giant, red "flagship" Cyrtohymena (Cyrtohymenides) aspoecki nov. subgen., nov. spec. Denisia, 13:369-382.

Foissner W, Adam H, 1983. Morphologie und morphogenese des bodenciliaten Oxytricha granulifera sp. n. (Ciliophora, Oxytrichidae). Zoologica Scripta, 12:1-11.

Hewitt EA, Müler KM, Cannone J, Hogan DJ, Gutell R, Pres- cott DM, 2003. Phylogenetic relationships among 28 spirotrichous ciliates documented by rDNA. Molecular Phylogenetics and Evolution, 29:258-267.

Kim YU, Lee JM, Kwon CB, Shin MK, 2012. Morphological redescriptions of three Cyrtohymena ciliates (Ciliophora: Sporadotrichida: Oxytrichidae) new to Korea. Journal of Species Research, 1:78-86.

Kwon CB, Shin MK, 2004. Two newly recorded ciliates, Oxytricha balladyna and O. longa (Ciliophora: Spirotrichea: Sporadotrichida) from Korea. Korean Journal of Systematic Zoology, 20:171-178.

Kwon CB, Shin MK, 2008. Two newly recorded ciliates, Oxytricha longigranulosa and O. marina (Ciliophora: Spirotrichea: Sporadotrichida) from Korea. Korean Journal of Systematic Zoology, 24:81-88.

Lamouroux JVF, Bory de Saint-Vincent JB, Deslongchamps E, 1824. Encyclopédie méthodique. Histoire naturelle des zoophytes, ou animaux rayonnés, faisant suite a l'histoire naturelle des vers de Bruguière. Vol. 2. Agasse, Paris, pp. 1-819.

Schlegel M, Elwood HJ, Sogin ML, 1991. Molecular evolution in hypotrichous ciliates: sequence of the small subunit ribosomal RNA genes from Onychodromus quadricornutus and Oxytricha granulifera (Oxytrichidae, Hypotrichida, Ciliophora). Journal of Molecular Evolution, 32:64-69.

Schmidt SL, Bernhard D, Schlegel M, Foissner W, 2007. Phylogeny of the Stichotrichia (Ciliophora; Spirotrichea) reconstructed with nuclear small subunit rRNA gene sequences: discrepancies and accordances with morphological data. The Journal of Eukaryotic Microbiology, 54:201-209.

Shin MK, Kim W, 1993. New records of three oxytrichid hypotrichs (Ciliophora: Hypotrichida: Oxytrichidae) from the Han River in Seoul, Korea. Korean Journal of Zoology, 36:223-230.

Song W, Wilbert N, 1989. Taxonomische Untersuchungen an Aufwuchsciliaten (Protozoa, Ciliophora) im Poppelsdorfer Weiher, Bonn. Lauterbornia, 3:2-221.

The Korean Society of Systematic Zoology, 1997. List of animals in Korea (excluding insects). Academy Publishing Co., Seoul, pp. 1-489.

Wilbert N, 1975. Eine Verbesserte Technik der Protargolimpragnation für Ciliaten. Mikrokosmos, 64:171-179.

Received September 10, 2012

Revised November 22, 2012

Accepted November 25, 2012 